\title{
Scientometric analysis on applications and recent research trends in electric vehicles for energy saving
}

\author{
Rakesh Dadhwal ${ }^{1}$, Raman Kumar $^{1}$, Jasgurpreet Singh Chohan ${ }^{1 *}$ and Jatinder Kaur $^{2}$ \\ ${ }^{1}$ Department of Mechanical Engineering, Chandigarh University, Punjab-140413, India \\ ${ }^{2}$ Department of Electronics and Communication Engineering, Chandigarh University, Punjab-140413, India \\ *Corresponding author E mail: jaskhera@gmail.com
}

\begin{abstract}
Electric vehicles are playing a major role in reduction of the environmental depletion, greenhouse effect and in energy saving. The electric vehicles provide cleaner and quieter ambiance, reduce the operating cost and saves the energy compared to fossil fuel powered vehicles because electric vehicles consume $75 \%$ of the total energy to run the vehicle. In this work scientometric analysis of electric vehicles for energy savings presented by the authors. The scientometric analysis is used to show the recent research trends and applications of various types of electric vehicles for energy saving. The Scopus database has been utilized to extract the data on existing research information on electric vehicles for energy saving. This scientometric analysis focuses on the documents published from 2011 to 2020 only to investigate the recent trends. The analysis showed the comparison between the top countries and top source titles who have published the articles and conference papers on electric vehicles for energy saving. VOSviewer software is used to develop the keyword network and co-authorship network.
\end{abstract}

Keywords: Electric vehicles, Energy saving, scientometric analysis, keywords analysis, Co-authorship, cluster

\section{Introduction}

Today our world is facing a problem of environmental deterioration due to the burning of fossil fuel in industrial and transportation sector [1]. The burning of fossil fuels emits hazardous and polluting elements in the environment. This emission of pollutant gases like carbon dioxide, carbon mono-oxide, nitrogen oxide give rise to greenhouse effect and environmental depletion. The fossil fuels are the backbone of our civilization. the resources of fossil fuels are limited and are continually depleting due to rapid growth of industrial sector and transportation using internal combustion engines [2,3]. According to the report of US Energy Information administration(EIA) 2012, the transportation sector consumes the $27 \%$ of the total energy consumption and contribute to $33.7 \%$ emission of greenhouse gases to the world's total emission of greenhouse gases [4].

So the researchers have to come up with an alternative energy solution to the fossil fuels [5] The industrial sector of the world is adopting renewable or green energy for electricity generation like solar, wind, geothermal etc. the transportation sector is also contributing by innovating and developing green vehicles with the objectives of eliminating the hazardous emission and energy saving [6,7]. The electric vehicle is one of the solutions to reduce the greenhouse emission and energy saving. Electric powered cars provide cleaner and quieter ambiance as well as reduce the operating cost compared to fossil fuel powered cars $[8,9]$

As per the report of US department of energy only $15 \%$ of the total fuel energy produced by the fossil fuel is used to run the car and its accessories while the rest of the energy losses through friction on a moving part and heat lose. While compared to conventional vehicles runs on fossil fuel, the electric vehicles consume more than the $75 \%$ of the total energy to run the car $[10,11,12]$. The countries around the world are developing electric vehicles based on new energy like hydrogen, natural gas, biogas, methanol, biodiesel etc. in order to reduce energy consumption and carbon dioxide emission. The vehicles can be classified mainly into three categories first one is internal combustion engine vehicles (ICEV) 
second one is hybrid electric vehicles (HEV) and the third one is all- electric vehicles (AEV) $[13,14]$. The four types of typical electrical vehicles are battery electric vehicle (BEV) which is an only battery powered without internal combustion engine (ICE), hybrid electric vehicle (HEV) which uses ICE and electric motors as power source, pug-in hybrid electric vehicle (PHEV) which has a larger electricity storage system as compared to $\mathrm{BEV}$, fuel cell hybrid electric vehicle (FCHEV) it is powered by fuel cell like PEMFC $[15,16,17]$

\section{Status of existing publications on}

\section{Electric vehicles for energy saving}

The quantitative data about the publications on electric vehicles for energy saving is obtained from Scopus database. This collected data is then analyzed by making entries in excel sheets. Thevarious outcomes or observations of the data analysis are as under: -

\subsection{Recent trends of Publications}

To observe the trend of publications, the publications data of previous ten years i.e. 2011 to 2020 is obtained from Scopus data base and it is observed that a total 1560 documents have been published from the year 2011 to 2020 on electric vehicles for energy saving. From the data extracted, the countries who have published more than 50 documents till 2020 are shortlisted and ranked according to their number of publications. Table 1 shows the top 9 countries and publications by them till 2020. The China has published the highest documents which is 1.7 times greater than the documents published by the USA and 3.7 times greater than the documents published by Germany who are at $2^{\text {nd }}$ and $3^{\text {rd }}$ place respectively after China. U.K, Japan, Italy, India, France and Canadaare placed at $4^{\text {th }}, 5^{\text {th }}, 6^{\text {th }}, 7^{\text {th }}, 8^{\text {th }}$, and $9^{\text {th }}$ position respectively based on the publication record on electric vehicles for energy saving.

Table.1 Top Countries

\begin{tabular}{|c|c|c|}
\hline $\begin{array}{c}\text { S. } \\
\text { No. }\end{array}$ & Country & Publications \\
\hline 1 & China & 493 \\
\hline 2 & United States & 293 \\
\hline 3 & Germany & 134 \\
\hline 4 & United Kingdom & 93 \\
\hline 5 & Japan & 82 \\
\hline 6 & Italy & 73 \\
\hline
\end{tabular}

\begin{tabular}{|c|c|c|}
\hline 7 & India & 69 \\
\hline 8 & France & 66 \\
\hline 9 & Canada & 62 \\
\hline
\end{tabular}

Figure. 1 shows that publications on electric vehicles for energy saving has increased more than 3 times in the past ten years i.e. from 2011 to 2020 and it is almost increasing every year

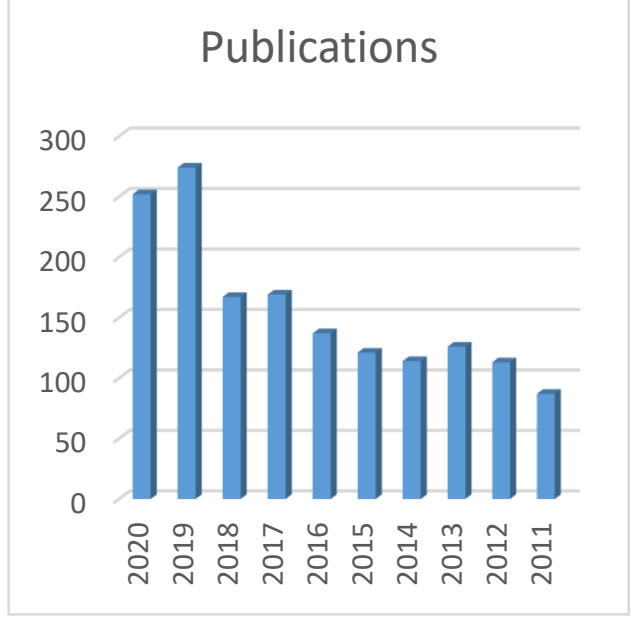

Fig 1. Number of publications reported each year

\subsection{Top source titles}

Table. 2 shows the top 10 source titles who have published the maximum publications. Along with the number of publications other details like H-index, category, SJR 2020, publisher and publication type is also mentioned in the table. It is observed from Table. 2 that all the top source titles come under the category of journals except the one i.e. Energy Procedia, which belongs to Conferences and Proceedings. Also the all source titles belong to Q1 and Q2 category of quartile. Five source titles belong to Q1 category and three source title belong to Q2 category of quartile. Out of ten source titles two source titles having the value of $\mathrm{H}$-index more than 200 and three source titles having the $\mathrm{H}$-index value more than 100. All the source titles of the list have been published by 6 different publishers while the Elsevier BV and Elsevier Ltd. Have published the three and two source titles respectively of the list. So it can be seen that none of the publisher have monopoly on the source titles.

Table.2 Top source titles

\begin{tabular}{|c|c|c|c|c|c|c|}
\hline $\begin{array}{c}\text { Source } \\
\text { title }\end{array}$ & $\begin{array}{c}\text { No of } \\
\text { publicati } \\
\text { ons }\end{array}$ & $\begin{array}{c}\text { H- } \\
\text { index }\end{array}$ & $\begin{array}{c}\text { Cate } \\
\text { gory }\end{array}$ & $\begin{array}{c}\text { SJR } \\
\mathbf{2 0 2 0}\end{array}$ & $\begin{array}{c}\text { Publicat } \\
\text { ion type }\end{array}$ & Publisher \\
\hline $\begin{array}{c}\text { SAE } \\
\text { Technical } \\
\text { Papers }\end{array}$ & 65 & 107 & Q2 & 0.3 & Journals & $\begin{array}{c}\text { SAE } \\
\text { Internationa } \\
1\end{array}$ \\
\hline $\begin{array}{c}\text { Applied } \\
\text { Energy }\end{array}$ & 47 & 212 & Q1 & 3.04 & Journals & Elsevier BV \\
\hline
\end{tabular}




\begin{tabular}{|c|c|c|c|c|c|c|}
\hline Energies & 46 & 93 & Q2 & 0.6 & Journals & $\begin{array}{c}\text { MDPI } \\
\text { Multidiscipl } \\
\text { inary Digital } \\
\text { Publishing } \\
\text { Institute }\end{array}$ \\
\hline Energy & 40 & 193 & Q1 & 1.96 & Journals & $\begin{array}{c}\text { Elsevier } \\
\text { Ltd. }\end{array}$ \\
\hline $\begin{array}{c}\text { IEEE } \\
\text { Transactio } \\
\text { ns On } \\
\begin{array}{c}\text { Vehicular } \\
\text { Technolog } \\
\text { y }\end{array}\end{array}$ & 30 & 178 & Q1 & 1.37 & Journals & $\begin{array}{c}\text { Institute of } \\
\text { Electrical } \\
\text { and } \\
\text { Electronics } \\
\text { Engineers } \\
\text { Inc. }\end{array}$ \\
\hline $\begin{array}{c}\text { Energy } \\
\text { Policy }\end{array}$ & 25 & 217 & Q1 & 2.09 & Journals & Elsevier BV \\
\hline $\begin{array}{c}\text { World } \\
\text { Electric } \\
\text { Vehicle } \\
\text { Journal }\end{array}$ & 24 & 18 & Q2 & 0.32 & Journals & MDPI AG \\
\hline $\begin{array}{c}\text { Energy } \\
\text { Procedia }\end{array}$ & 24 & 81 & - & 0.47 & $\begin{array}{l}\text { nonfere } \\
\text { Proceedi } \\
\text { ngs }\end{array}$ & \\
\hline $\begin{array}{c}\text { Sustainabi } \\
\text { lity } \\
\text { Switzerlan } \\
\text { d }\end{array}$ & 24 & $9 l s e v i e r$ BV \\
\hline $\begin{array}{c}\text { Transport } \\
\text { ation } \\
\text { Research } \\
\text { Part D } \\
\text { Transport } \\
\text { And } \\
\text { Environm } \\
\text { ent }\end{array}$ & 23 & 99 & 1.6 & Journals & $\begin{array}{c}\text { Elsevier } \\
\text { Ltd. }\end{array}$ \\
\hline
\end{tabular}

It can also be seen in the Table 3 that There are one source titles who haves 2019 value more than 3, two source titles have SJR 2019 value more than two and three source titles have SJR 2020 value more than one

\subsection{Top authors of top institutes}

A table of top 10 institutes and their top author is prepared on the basis of number of publications by them on electric vehicles for energy saving from 2011 to 2020, shown as Table 3.Table 3 shows that Tsinghua University has published highest documents on electric vehicles for energy saving and Mansour, C. is not only the top author in Mines ParisTech and Lebanese American University but also the top author among all the authors in the list with 10 publications each in the both institutes followed by $\mathrm{Li}, \mathrm{K}$. of Tsinghua University and He, H. of Beijing Institute of Technology with 09 publications by each. It can also be seen that top three institutes of the table 3 collectively have published the more documents than the total documents published by the rest of the seven institutes. Thus it shows that these three institutes are actively doing research on electric vehicles for energy saving. Chongqing University, Shanghai Jiao Tong University, University of Michigan, Ann Arbor and Mines ParisTech have published 17 documents each while Wuhan University of Technology and Lebanese American University have published 16 documents each from 2011 to 2020.

Table 3 Top authors of top institutes

\begin{tabular}{|l|c|l|c|}
\hline \multicolumn{1}{|c|}{ Institute Name } & $\begin{array}{c}\text { Publi } \\
\text { catio } \\
\text { ns }\end{array}$ & $\begin{array}{c}\text { Top author of } \\
\text { the Institute }\end{array}$ & $\begin{array}{c}\text { No of } \\
\text { Publica } \\
\text { tions }\end{array}$ \\
\hline $\begin{array}{l}\text { Tsinghua } \\
\text { University }\end{array}$ & 46 & $\mathrm{Li}, \mathrm{K}$. & 09 \\
\hline $\begin{array}{l}\text { Beijing Institute of } \\
\text { Technology }\end{array}$ & 42 & He, H. & 09 \\
\hline $\begin{array}{l}\text { Jilin University } \\
\text { Argonne National } \\
\text { Laboratory }\end{array}$ & 39 & Chu, L. & 07 \\
\hline $\begin{array}{l}\text { Chongqing } \\
\text { University }\end{array}$ & 17 & Hu, X. & 05 \\
\hline $\begin{array}{l}\text { Shanghai Jiao Tong } \\
\text { University }\end{array}$ & 17 & Chen, J. & 04 \\
\hline $\begin{array}{l}\text { University of } \\
\text { Michigan, Ann } \\
\text { Arbor }\end{array}$ & 17 & Peng, H. & 04 \\
\hline Mines ParisTech & 17 & Mansour, C. & 10 \\
\hline $\begin{array}{l}\text { Wuhan University } \\
\text { of Technology }\end{array}$ & 16 & Tan, G. & 04 \\
\hline $\begin{array}{l}\text { Lebanese American } \\
\text { University }\end{array}$ & 16 & Mansour, C. & 10 \\
\hline
\end{tabular}

\section{Keywords Analysis}

For keyword analysis of the publication data is extracted from Scopus. Two types of documents i.e. article and conference papers are considered keyword analysis and total 1560 number of documents are extracted from the Scopus data base. For developing the keyword network of 1560 documents as articles and conference papers only author keywords are scanned. Total 3582 keywords are scanned from the 1560 documents and the final keyword network is developed for only 10 keywords related to energy saving with the minimum occurrence of 20. It can be seen in the appendix 1 that there is formation of three clusters of keywords, which have been differentiated with different colors. In cluster 1 and cluster 2 there are 04 items in each cluster. While in Cluster 3 there is only 02 items. From the keyword network analysis, it is observed that electric vehicle and energy management has the highest occurrence and highest total link strength. Energy management, hybrid electric vehicles and energy saving have high relatedness to electric while energy storage, energy efficiency, renewable energy and energy consumption 
are the least explored areas of electric vehicles. So the researchers should focus on these areas of electric vehicles for further research on electric vehicles because there is a lot of scope in these areas.

\subsection{Co-authorship analysis between countries:}

Appendix. 2 shows the co-authorship between the countries. VOSviewer is used to analyze trend of the coauthorship between the various countries. The data extracted from the Scopus is scanned by taking minimum 20 numbers of documents published a country and with at least 10 citations of the country. Total 94 countries are obtained from all documents that meet 16 thresholds. From Co-authorship analysis between countries it is observed that China and USA has the highest documents and highest total link strength respectively among the all 94 countries. However, the USA has more citations than the China, instead of very less number of documents as compared to China. As far as concern of India it is observed that India is coauthoring with USA, France and Canada only. As China is world leader in publications on electric vehicle for energy saving so the Indian researchers should also collaborate with the researchers of China.

It is also observed that Taiwan is co-authoring only with the UK and China

\section{Conclusions:}

A scientometric analysis is done to present the detailed quantitative measure on existing research on electric vehicles for energy savings. It has been observed that the overall trend of publications on electric vehicles for energy saving has increased more than three times from 2011 to 2020. Although the source titles Applied energy and Energy policy are at $2^{\text {nd }}$ and $6^{\text {th }}$ but having value of $\mathrm{H}$-index 212 and 217 respectively which is much greater than the $\mathrm{H}$-index value of source title at $1^{\text {st }}$ rank. Also the both source titles belongs to Q1 category and having the value of SJR2020 as 3.04 and 2.09 respectively which is also greater than the source title at $1^{\text {st }}$ rank. So the researchers should focus on publishing his documents in these source titles. Tsinghua University has published the highest documents on electric vehicles for energy saving and Mansaur, C. has published the highest documents on electric vehicles for energy saving in two different institutes. Keywords network shows the occurrence and relatedness of different author keywords with electric vehicles for energy saving. Moreover, from the co-authorship network between the countries it has been concluded that India has not collaborated with China while China has published the highest documents on electric vehicles for energy saving. Hence, the Indian researchers should focus on collaborating with the researchers of China.

\section{References:}

1. S. F. Tie and C. W. Tan, Renewable and sustainable energy reviews, 20, 82-102 (2013).

2. M. F. M. Sabri, K. A. Danapalasingam and M. F. Rahmat Renewable and Sustainable Energy Reviews, 53, 1433-1442 (2016).

3. S. H. Mohr, J. Wang, G. Ellem, J. Ward and D. Giurco, Fuel, 141, 120-135 (2015).

4. International Energy Outlook 2011. U.S. Energy Information Administration (EIA) and International Energy Agency; 2011

5. Y. X. Lü, J. Wu, Y. Lian, C. Zhang, P. Chen, Wang and L. Meng, Energy Conversion and Management, 205, 112474 (2020)

6. A. Ajanovic and R. Haas, Fuel cells, 19(5), 515529 (2019).

7. S. M. Lukic, J. Cao, R. C. Bansal, F. Rodriguez and A. Emadi, IEEE Transactions on industrial electronics, 55(6), 2258-2267 (2008).

8. S. Sorrell, J. Speirs, R. Bentley, R. Miller and Thompson, Energy, 37(1), 709-724 (2012).

9. N. A. Owen, O. R. Inderwildi and D. A. King, Energy policy, 38(8), 4743-4749 (2010).

10. J. A. Mathews, Futures, 46, 10-22 (2013).

11. E. K. Stigka, J. A. Paravantis and G. K. Mihalakakou, Renewable and sustainable energy Reviews, 32, 100-106 (2014).

12. R. Schmidt and M. Iyengar, In 2008 11th Intersociety Conference on Thermal and Thermomechanical Phenomena in Electronic Systems 1255-1275 (2008).

13. K. T. Chau and C. C. Chan, Proceedings of the IEEE, 95(4), 821-835 (2007).

14. G. R. Parsons, M. K. Hidrue, W. Kempton and M. P. Gardner, Energy Economics, 42, 313-324 (2014).

15. H. S. Das, C. W. Tan, C. W. and A. H. M. Yatim, Renewable and Sustainable Energy Reviews, 76, 268-291 (2017).

16. W. Liu, Introduction to hybrid vehicle system modeling and control. John Wiley \& Sons. (2013).

17. S. Ahmadi, S. M. T. Bathaee and A. H. Hosseinpour, Energy Conversion and Management, 160, 74-84 (2018). 


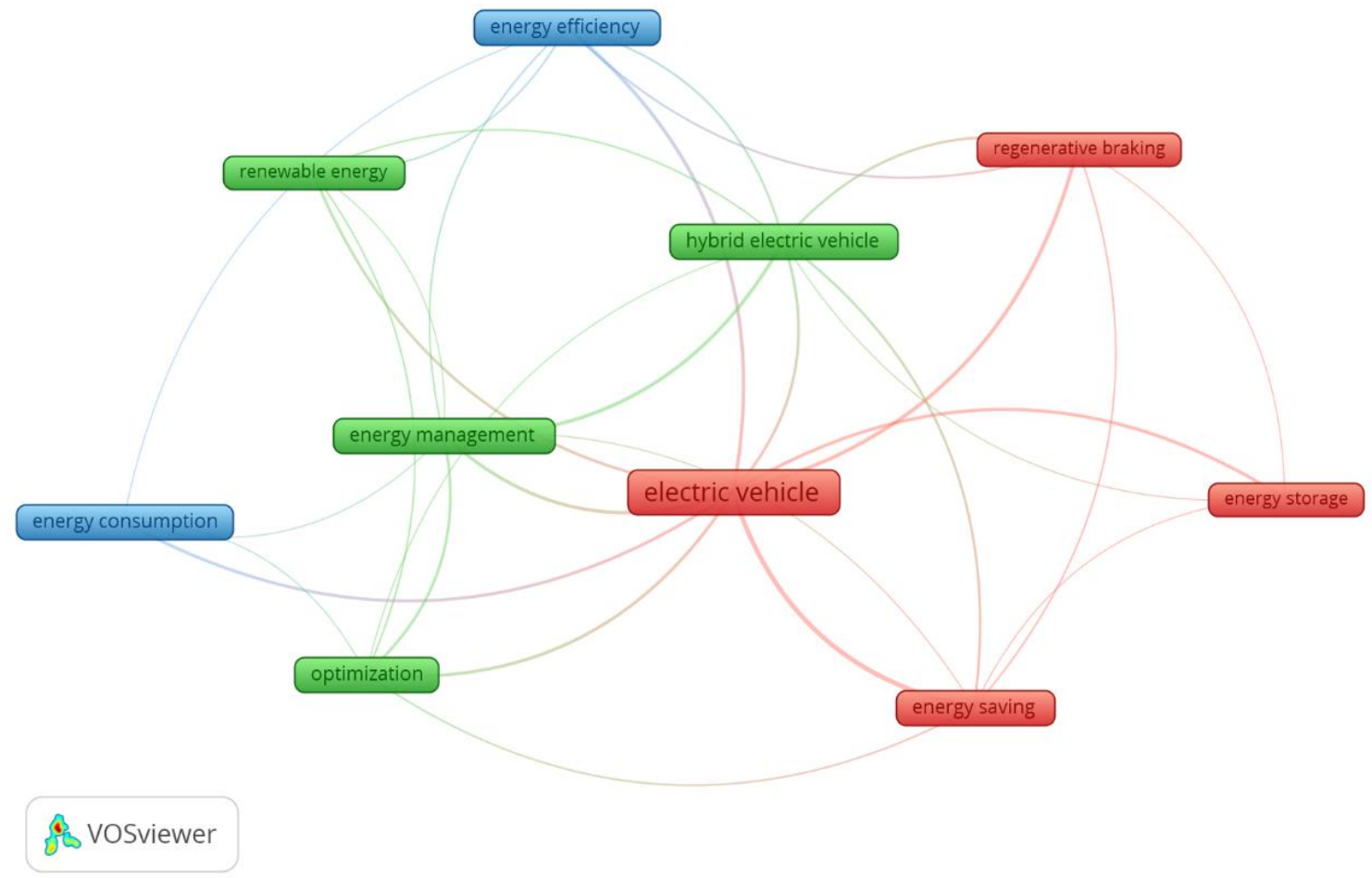

Appendix 1. Keywords analysis

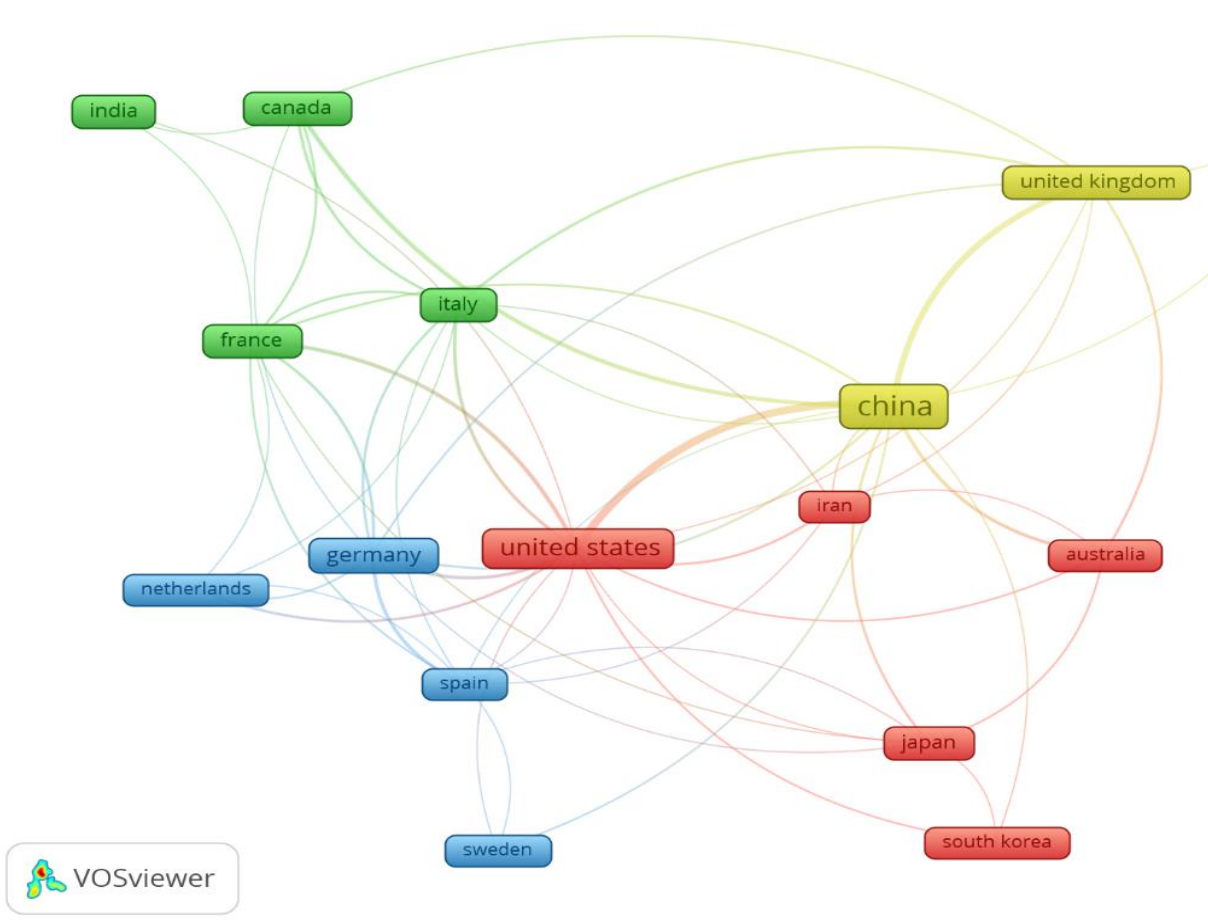

Appendix 2. Co-authorship analysis 